\title{
Comparison of a Biosensor and a Commercial UV- Visible Method for Measuring Hexavalent Chromium in Liquid Medium
}

\section{Melany Avellaneda}

Pontificia Universidad Catolica del Ecuador Sede Ibarra

Santiago Xavier Mafla ( $\square$ sxmafla@pucesi.edu.ec)

Pontificia Universidad Catolica del Ecuador Sede Ibarra https://orcid.org/0000-0002-1252-3357

\section{Moraima Mera}

Pontificia Universidad Catolica del Ecuador Sede Ibarra

\section{Research Article}

Keywords: Escherichia coli, gene transformation, plasmid

Posted Date: December 6th, 2021

DOI: https://doi.org/10.21203/rs.3.rs-1050540/v1

License: (c) (1) This work is licensed under a Creative Commons Attribution 4.0 International License.

Read Full License 


\section{Abstract}

The objective of the research was to contrast two methods for the quantification of hexavalent chromium. The first method is the biosensor that from the gene transformation of the cells of Escherichia coli, was incorporated by electroporation the plasmid pTOP Blunt V2, synthesized with luxA genes that provides luminescence through the catalytic activity of the luciferase top and chr genes that give the bacteria resistance to chromium. The second method is the application of the UV-visible colorimetric technique. Chromium was analysed at different concentrations, from $0.05 \mathrm{mg} \mathrm{l}^{-1}$ (maximum allowable limit for human consumption); $0.1 \mathrm{mg} \mathrm{I}^{-1} ; 0.2 \mathrm{mg} \mathrm{I}^{-1} ; 0.4 \mathrm{mg} \mathrm{I}^{-1} ; 0.8 \mathrm{mg} \mathrm{I}^{-1}$ and $1 \mathrm{mg} \mathrm{I}^{-1}$ with 5 replicates, subsequent to this, the two methods of chromium analysis were applied in river samples, thus obtaining that the biosensor in concentrations of $2 \times 10^{6} \mathrm{CFU}$ of $\mathrm{E}$. coli, has a margin of error of $1.4 \%$, a result derived from the coefficient of determination of the absorbance of chromium, unlike the UV-visible method with the colorimetric equipment, which presented a reading error of $3.9 \%$.

\section{Introduction}

One of the methodologies currently applied to determine and quantify contaminants present in water are chemical analyzes, which can reach the detection of parts per trillion (ppt); since they are considered the most sophisticated. These chemical analyzes require pretreatment to preserve the sample during transfer to the laboratory, to avoid altering the results. This occurs, for example, in gas chromatography and mass detection analyzes; expensive and large equipment that requires its use in the laboratory (Schoffer et al., 2011).

Another type of process used corresponds to biological tests or bioassays; Some of the biosensors are devices composed of bacteria, combining biotechnology and microelectronics to form an analytical device, reducing the time used for the analysis of contaminants in the water. In this way, it is desired to implement new processes for the detection of toxic pollutants, efficiently replacing conventional methods at lower cost and time (Reyes, 2016).

The World Health Organization (WHO) considers chromium as one of the 10 most toxic and harmful transition metals for health and the environment, in its hexavalent form; currently exceeding the maximum permissible limits of $0.05 \mathrm{mg} \mathrm{l}^{-1}$ for water for human consumption (WHO, 2018).

The National Water Quality Strategy (ENCA) indicates that in Ecuador the quality of water has deteriorated in recent years due to anthropic activity and industrial chemical processes, producing waste with toxic organic and inorganic pollutant loads, such as chromium +3 and chromium +6 which are difficult to remove and together with the poor application of environmental regulations, progressive damage to the environment is being generated (ENCA, 2016).

At the regional level, the deficient public service, the lack of control of the emission of ecological flow, indirectly cause the discharge of uncontrolled effluents into the environment by industrial and agricultural 
activities, generating mixed-type waste due to the lack of wastewater collection systems. This does not allow the correct separation of industrial and urban effluents, generating poor management of water resources, loss of biodiversity, loss of environmental services and deterioration of ecosystems (Llerena and Aguay, 2018).

The objective of the research was to compare two methods for the quantification of hexavalent chromium, these being a field method known as colorimetry and the use of a bacterial biosensor that was manufactured for this study. This research has been developed to broaden the field of study, regarding the methodologies used for the detection of hexavalent chromium in water sources, whether they are for human consumption, irrigation or water trough; thus guaranteeing the protection of the environment, being a shared responsibility between society and the government, that is, reducing the impacts of waste, inputs and processes; with the aim of achieving adequate environmental management in small, medium and large industries (Ortiz and Carmona, 2015).

\section{Materials And Methods}

This research was carried out in the Biotechnology Laboratory of the School of Agricultural and Environmental Sciences of the Pontificia Universidad Católica del Ecuador Sede Ibarra.

\section{Elaboration of the biosensor}

For the elaboration of the biosensor, the sequence of the chr gene that gives the bacterium resistance to chromium and the sequence of the lux operon to generate the optical response of the biosensor was searched in the registry of community collection of genetic sequences available in iGEM (International Genetically Engineered Machine) to later assemble the plasmid in the Biotechnology company "Humanazing Genomics @ MAROGEN Inc.". The result being the genetic synthesis described in Table 1 (MACROGEN Inc, 2018).

The result of the assembly of the gene sequences produced a plasmid with a size of 1,847 base pairs (bp) and a guanine and cytosine (GC) percentage of $60.23 \%$.

For the modification of the genes of the $E$. coli bacteria, the Electroporation method described by Bastida and Levi (2019) was used, where a Thermo Scientific ULT1230A freezer was used to prepare the competent cells, since these must be preserved at a temperature of $4^{\circ} \mathrm{C}$. After this, $10 \mu$ of the manufactured plasmid plus $20 \mu \mathrm{l}$ of the competent cells were taken and added in a $2 \mathrm{ml}$ eppendorf tube, this mixture was centrifuged and placed in the freezer again.

For the transformation of $E$. coli, the Electroporation Neon Device equipment was set at 2500 volts for 4 milliseconds and two pulses for the transmutation of E. coli (Gómez and Garns, 2003). To prepare the Electroporation equipment, the Neon Pipette Station was connected in which the Neon Tube cuvette was inserted with $3 \mathrm{ml}$ of electrolytic buffer (Electrolytic Buffer) with a temperature of $2^{\circ} \mathrm{C}$ to $4^{\circ} \mathrm{C}$ (Gómez and Garns, 2003). 
LB Broth Base broth was prepared in a $250 \mathrm{ml}$ boeco bottle, according to the manufacturer's instructions. Next, $10 \mathrm{ml}$ of this mixture was dispensed into 24 test tubes and sterilized with the help of the ICAN CLAVE autoclave for 40 minutes. Having the 24 test tubes already sterilized, hexavalent chromium concentrations of $0.05 \mathrm{mg} \mathrm{I}^{-1}$ were placed; $0.1 \mathrm{mg} \mathrm{I}^{-1} ; 0.2 \mathrm{mg} \mathrm{I}^{-1} ; 0.4 \mathrm{mg} \mathrm{I}^{-1} ; 0.8 \mathrm{mg} \mathrm{I}^{-1}$ and $1.0 \mathrm{mg} \mathrm{I}^{-1}$.

Next, $100 \mu$ l, equivalent to $2 \times 10{ }^{6} \mathrm{CFU}$ of the transformed cells, was added to each test tube, incubated for 2 hours and chromium analysis was carried out by the EPOCH Microplate Spectrophotometer method, where $100 \mu \mathrm{l}$ was added to the cells. samples that were previously incubated, placing the different chromium concentrations in each column of the microplate and 5 repetitions in each row. With the help of the EPOCH Microplate Spectrophotometer from Biotec Instruments and a computer program for data analysis Gen5 Software, the absorbance analysis of the samples was carried out to obtain the calibration curve (Macías et al., 2019).

\section{Analysis of the process for the detection of chromium using a modified E. coli strain.}

The E. coli bacteria were seeded in quantities of $2 \times 10^{6} \mathrm{CFU}$ genetically transformed in test tubes with LB Broth broth from the manufacturer LAB a Neogen Company (Luria Bertani) ${ }^{\circledR}$, a medium that does not intervene in the reaction between the bacteria and the metal and provides the necessary nutrients for the bacteria, plus the transition metal, verifying their resistance and the optical response of the luciferase gene and the interaction between the metal and the medium (García et al., 2005).

For the analysis of the biosensor to detect chromium, liquid samples (Figure 1) were qualified with hexavalent chromium at known concentrations of $0.05 \mathrm{mg} \mathrm{I}^{-1} ; 0.1 \mathrm{mg} \mathrm{I}^{-1} ; 0.2 \mathrm{mg} \mathrm{I}^{-1} ; 0.4 \mathrm{mg} \mathrm{I}^{-1} ; 0.8 \mathrm{mg}$ $\mathrm{I}^{-1}$ and $1.0 \mathrm{mg} \mathrm{I}^{-1}$; indicating the presence of the metal before the different levels of luminosity directly proportional to the concentration of the toxic agent, this being the higher the concentration of metal, the more intensity of the luminescence.

In the research carried out by Huelves (2008), the enzyme that catalyzes the luminescence reaction is encoded in the enzymatic protein of luciferase, an operon that was modified together with the chromium resistance genes by inserting into the $E$. coli bacteria, thus obtaining a medium that translates into light emission.

\section{Field application of the two methods to quantify hexavalent chromium}

For the field application of the two methods used to quantify hexavalent chromium, the research of Jurado et al. (2017). The first method suggested uniformly sectioning the total length of the river, which consisted of $12.71 \mathrm{~km}$, identifying accesses, the presence of contamination by wastewater discharges (Figure 2) and agricultural activities, a method applied to date in the monitoring of river samples.

Two levels were raised; the macro location that determined the most representative sections according to the total length of the Pichaví river; the micro-location that implied the equivalent division of the total 
length of the river, with a distance of $2 \mathrm{~km}$ between each point (Figure 3), a distance that must be considered according to the different methods applied in the field for the collection of a sample, due to the estimation of the total uniform mixture of water between each section, thus generating a total of 6 points for the collection of water samples (Jurado and Mercado, 2017).

In the research, a statistical design of paired plots was applied by applying the t-Student test, in order to see the relationship between the methods applied for the measurement of hexavalent chromium and define the hypothesis. For the normality of the data, the Shapiro - Wilk test (Rossiter, 2014) was used. Two tests were used being these cases: the first test used 6 concentrations of hexavalent chromium of $0.05 \mathrm{mg} \mathrm{I}^{-1} ; 0.1 \mathrm{mg} \mathrm{I}^{-1} ; 0.2 \mathrm{mg} \mathrm{I}^{-1} ; 0.4 \mathrm{mg} \mathrm{I}^{-1} ; 0.8 \mathrm{mg} \mathrm{I}^{-1}$ and $1.0 \mathrm{mg} \mathrm{I}^{-1}$; This served to standardize the measurement method and verify that bacteria have the potential to measure chromium. Subsequently, 6 liquid samples were taken from the Pichaví river and the biosensor technique was compared with a commercial and field technique.

To compare the efficiency of the two methods, standard liquid samples and river samples were analyzed by the EPOCH Microplate Spectrophotometer from Biotec Instruments and with the SMART 2 Colorimeter from LaMotte Company, comparing the normality of the results by means of a Shapiro test. - Wilk.

\section{Results}

\section{Analysis of the physical-chemical parameters of the river}

According to the results obtained in Table 2, the conductivity parameter of the 6 river water samples is within the permissible limits of the TULSMA; Total dissolved solids with a minimum value of $475 \mathrm{mg} \mathrm{I}^{-1}$ and a maximum of $516 \mathrm{mg} \mathrm{I}^{-1}$ of the 6 water samples, indicate values within the permissible ones. The results of the $\mathrm{pH}$ and $\mathrm{BOD}$ parameters indicate that the state of water quality in the environment is optimal for the development of organic matter and microorganisms, essential for oxygenation.

\section{Evaluation of the biosensor with standard liquid samples and samples from the Pichaví river contaminated with the transition metal. \\ Biosensor applied to standard liquid samples}

Figure 4 shows the absorbance curve of the equipment, with a margin of error of $1.6 \%$ when quantifying a sample. The coefficient of determination, also known as $\mathrm{R}^{2}$, has a value of 0.9841 , which is very close to 1 and through this result it is known that it is a reliable method to quantify hexavalent chromium.

To know the normality of the data obtained from the different chromium concentrations submitted by the biosensor, the Shapiro-Wilk test was applied, indicating the normal distribution of the data.

The result obtained in Table 3 represents the $P$ value in the normality of the data. In the Shapiro-Wilk test, with a P-value of 0.11 , it was obtained that in the values of the amount of chromium absorbance at different concentrations there is a normality of distribution. 


\section{Biosensor applied to river samples}

To know the normality and homogeneity of the data obtained from the different samples taken from the river submitted by the biosensor, the Shapiro-Wilk and Levene test was applied, indicating the normal distribution of the data and their homogeneity.

The data obtained in Table 4 represent the $\mathrm{P}$ value, both for normality and homogeneity. In the ShapiroWilk test, with a P-value of 0.95 , it was obtained that in the data of the amount of Chromium absorbance there is normality.

On the other hand, it is mentioned that all the data have homogeneity of variance in their distribution since the $P$-value $=0.35$ of the $F$ is greater than the 0.05 level of significance, thus accepting the null hypothesis.

Comparison of the efficiency of the biosensor by the EPOCH Microplate Spectrophotometer method (BIOSENSOR) vs the UV-visible technique (Colorimeter).

\section{EPOCH Microplate Spectrophotometer (BIOSENSOR) vs UV- visible technique (Colorimeter) at known chromium concentrations}

For the comparison of the two methods applied to know their efficiency through a quantitative measurement at known chromium concentrations, it is distributed with 2 degrees of freedom, providing the hypothesis of equality of the means.

According to the results obtained, the statistical value calculated for the p-value of the t-Student test is 0.02 ; less than the significance level of 0.05 , in the concentration of $0.05 \mathrm{mg} \mathrm{I}^{-1}$ of hexavalent chromium, in this way the null hypothesis is rejected.

According to the results obtained, the calculated statistical value of the p-value of the t-Student test is 0.00024 ; less than the significance level of 0.05 , in the concentration of $0.1 \mathrm{mg} \mathrm{l}^{-1}$ of hexavalent chromium, in this way the null hypothesis is rejected.

According to the results obtained, the calculated statistical value of the p-value of the t-Student test is 0.07 ; greater than the significance level of 0.05 ; in this way the null hypothesis is accepted.

According to the results obtained, the calculated statistical value of the p-value of the t-Student test is 0.07 ; greater than the significance level of 0.05 ; in this way the null hypothesis is accepted.

According to the results obtained, the calculated statistical value of the p-value of the t-Student test is 0.002 ; less than the significance level of 0.05 ; in this way the null hypothesis is rejected. 
According to the results obtained, the statistical value calculated for the $p$-value of the t-Student test is 0.02 ; less than the significance level of 0.05 ; in this way the null hypothesis is rejected.

According to the statistical analysis of the t-Student test applied for the quantification of hexavalent chromium by applying the EPOCH Microplate Spectrophotometer method (biosensor) and the UV-visible method by Colorimetry, the null hypothesis is rejected, since, the 6 different concentrations of chromium quantified, 4 of the concentrations indicate that the EPOCH Microplate Spectrophotometry method is different from the UV-visible method by colorimetry, accepting the alternative hypothesis.

\section{EPOCH Microplate Spectrophotometer (BIOSENSOR) vs UV- visible technique (Colorimeter) applied in the field}

For the analysis of river samples, the two methods were used. EPOCH Microplate Spectrophotometry is different from the UV-visible method by colorimetry, applying a third method (Table 11); Atomic Absorption Spectroscopy, method suggested by (Peraza, 2011) for its precision, linearity of detection and quantification of metals.

\section{Discussion}

\section{Analysis of the physical-chemical parameters of the river}

The results of the following parameters analyzed from the samples collected from the Pichaví River indicated in Table 2 (do not include metals), in accordance with the maximum permissible freshwater quality limits of Book VI Annex 1 of the Environmental Quality Standard and Effluent Discharge: Water Resource of the Unified Text of Secondary Legislation, Environment of Ecuador (TULSMA), are within the maximum permissible limits such as conductivity and salinity, thus complying with the necessary requirements of a body of water. sweet (TULSMA, 2018).

As Chaparro (2020) mentions, the determination of some physical-chemical parameters indicate the quality of water present in the environment to be analyzed, such as $\mathrm{pH}$ and BOD that are responsible for self-purification, causing the elimination of toxic polluting residues.

\section{EPOCH Microplate Spectrophotometer (BIOSENSOR) vs UV- visible technique (Colorimeter) applied in the field}

To determine the efficiency of the methods applied to quantify chromium, the results of the different samples taken from the river were compared; For sample 2 it was obtained that the biosensor quantified $0.19 \mathrm{mg} \mathrm{l}^{-1}$ of chromium with a difference of $0.01 \mathrm{mg} \mathrm{I}^{-1}$ in relation to the analysis performed by Atomic Absorption.

According to Álvarez et al. (2013), the atomic absorption spectroscopy method is a validated test with reliable results when quantifying metals, being the most favorable due to the curve that is calibrated from a standard that passes through a flame and is crossed by a beam of light that contains specific waves of 
the analyte, in this case hexavalent chromium, with precision and accuracy results, recommended for the comparison of quantified results with other methods.

When comparing the colorimetric method with the Atomic Absorption method of the result of sample two, a difference of $0.08 \mathrm{mg} \mathrm{I}^{-1}$ is obtained, and with a difference of $0.07 \mathrm{mg} \mathrm{I}^{-1}$ with the EPOCH method (BIOSENSOR).

Corroborating with the results obtained from the t-Student test, where the null hypothesis is rejected in most of the chromium concentrations quantified, where the EPOCH Microplate Spectrophotometry method (biosensor) and the UV-visible method by Colorimetry are totally different when measuring hexavalent chromium due to the comparison between the different results obtained by the applied methods.

\section{Conclusions}

Bacterial biosensors are an alternative as qualitative and quantitative analytical devices for metals, due to the reaction between the bacteria and the metal producing luminescence, which indicates the presence of the toxic agent analyzed thanks to the lux operon that was inserted into the bacteria and the resistance to chromium that was given by the chr genes.

The analyzes carried out with the bacterial biosensor show that it has a high specificity regarding the measurement of hexavalent chromium, in concentrations of $0.05 \mathrm{mg} \mathrm{l}^{-1}$ to $1.0 \mathrm{mg} \mathrm{I}^{-1}$ with an error of $1.6 \%$, thus ensuring that the elaborated biosensor is effective in terms of metal quantification, accepting the hypothesis raised in the research.

The efficiency of the biosensor before the quantitative analysis in comparison with the UV-visible method is more efficient, because the UV-visible method uses a field equipment, which presents a margin of error caused by the systematic factors in the processes of sampling, forcing the application of control samples, increasing residual sample.

\section{Bibliographic}

1. Álvarez, C., Acevedo, R., \& Severiche, C. (2013). Evaluación analítica para la determinación de aluminio, bario y cromo en aguas, por espectroscopia de absorción atómica con llama óxido nitrosoacetileno. https://repository.usc.edu.co/bitstream/handle/20.500.12421/744/348-681-1-SM.pdf? sequence=1\&isAllowed=y

2. Bastida Ramírez, \& Levi Jafet. (2019). CARACTERIZACIÓN DEL CAMBIO EN LA RELACIÓN RNA/PROTEÍNA DE CEPAS DE Escherichia coli CON MODIFICACIONES EN LA MAQUINARIA TRADUCCIONAL. http://ri.uaemex.mx/handle/20.500.11799/106062

3. Bru Huelves. (2008). Desarrollo de bioensayos para el seguimiento toxicológico de procesos de tratamientos de aguas. Universidad Rey Juan Carlos. http://hdl.handle.net/10115/5548 
4. Chaparro, S. (2020). Determinación de la capacidad de autodepuración de un tramo del río Tunjuelo respecto al pH y a la demanda biológica de oxígeno (DBO).

5. ENCA. (2016). ESTRATEGIA NACIONAL DE CALIDAD DEL AGUA. https://www.controlsanitario.gob.ec/wp-content/uploads/downloads/2019/05/Estrategia-Nacionalde-Calidad-del-Agua_2016-2030.pdf

6. García, C. D., Clavijo, G., \& Cols, Y. (2005). Circuitos integrados bioinformadores bioluminiscentes (CIBB). In CIRCUITOS INTEGRADOS BIOINFORMADORES BIOLUMINISCENTES. CIBB.

7. Gómez García, A., \& Garns, P. M. (2003). Papel del cromo y el cinc en el metabolismo de la insulina.

8. Llerena, S., \& Aguay, A. (2018). Riesgos de la contaminación del río Salinas proveniente del vertido de aguas residuales industriales en la parroquia Salinas perteneciente al cantón Guaranda.

9. M.A. Jurado, \& I.D. Mercado. (2017). Revisión sistemática de técnicas no convencionales para la evaluación de la calidad del agua de ríos contaminados con plaguicidas. http://www.scielo.org.co/pdf/ecei/v11n21/1909-8367-ecei-11-21-00056.pdf

10. Macías-Rioseco, M., Caffarena, R. D., Fraga, M., Silveira, C., Giannitti, F., Cantón, G., Hecker, Y. P., Suanes, A., \& Riet-Correa, F. (2019). Abortion outbreak caused by Campylobacter fetus subspecies venerealis and Neospora caninum in a bovine dairy herd. Revista Mexicana De Ciencias Pecuarias, 10(4), 1054-1063. https://doi.org/10.22319/rmcp.v10i4.5008

11. MACROGEN Inc. (2018). Macrogen Online Sequencing Order System. https://dna.macrogen.com/mypage/retrieveOrderList.do?menuCd=MYP300

12. Nidia Ortiz, \& Juan Carlos Carmona. (2015). APROVECHAMIENTO DE CROMO ELIMINADO EN AGUAS RESIDUALES DE CURTIEMBRES (SAN BENITO, BOGOTÁ), MEDIANTE TRATAMIENTO CON SULFATO DE SODIO. https://www.redalyc.org/pdf/3217/321733015009.pdf

13. Organización Mundial de la Salud. (2018). ii Catalogación por la Biblioteca de la OMS. https://www.who.int/water_sanitation_health/dwq/gdwq3_es_fulll_lowsres.pdf?ua=1

14. Peraza, C. V. (2011). Evaluación de un método analítico para la determinación de níquel y plomo en sedimento de mar por espectroscopia de absorción atómica Evaluation of an analytical method for the determination of nickel and lead in marine sediments by atomic absorption spectroscopy (Vol. 15, Issue 1).

15. Rossiter, D. G. (2014). Introduction to the R Project for Statistical Computing for use at ITC. http://www.itc.nl/personal/rossiter

16. Schoffer, J. T., Bustos-López, C., Sotomayor, P., Mattar, C. A., González, A., Robles, C., Samsing, F., Acevedo, O., \& Valdovinos, C. E. (2011). Aplicación del bioensayo EROD-H4IIE para la determinación de dioxinas en carnes de pollos broiler: Un estudio de equivalencia con la cromatografía de gases de alta resolución acoplada a espectrometría de masas de alta resolución. Archivos de Medicina Veterinaria, 43(3), 259-266. https://doi.org/10.4067/S0301-732X2011000300008

17. TULSMA. (2018). NORMA DE CALIDAD AMBIENTAL Y DE DESCARGA DE EFLUENTES: RECURSO AGUA. 
18. Yulieth Reyes, I. V. O. T. M. D. L. E. E. G. J. (2016). Contaminación por metales pesados: Implicaciones en salud, ambiente y seguridad alimentaria - Dialnet. Ingeniería Investigación y Desarrollo. https://dialnet.unirioja.es/servlet/articulo?codigo $=6096110$

\section{Tables}

Table 1. Characteristics of the plasmid sequence

\begin{tabular}{ll} 
Gene size & 1,847 bp \\
\hline GC\% & $60.23 \%$
\end{tabular}

Note. Data obtained from the technical description of the plasmid

Source: MACROGEN Inc. (2019).

Table 2. Result of the physical-chemical analysis of the samples collected from the Pichaví river

\begin{tabular}{|c|c|c|c|c|c|c|c|}
\hline Physical-chemical parameters & $\begin{array}{l}\text { Maximum } \\
\text { allowable limit }\end{array}$ & M1 & M2 & M3 & M4 & M5 & M6 \\
\hline Conductivity $\mu \mathrm{s}$ & $0-1000$ & 739 & 733 & 697 & 703 & 679 & 687 \\
\hline Total dissolved solids $\mathrm{mg} \mathrm{l}^{-1}$ & 1600 & 516 & 514 & 490 & 492 & 475 & 489 \\
\hline Salinity ppm & $0-450$ & 357 & 356 & 336 & 340 & 327 & 332 \\
\hline Nitrites $\mathrm{mg} \mathrm{l}^{-1}$ & $0-10$ & 0.25 & 0.23 & 0.25 & 0.24 & 0.18 & 0.23 \\
\hline Nitrates $\mathrm{mg} \mathrm{l}^{-1}$ & $0-10$ & 0.5 & 0.5 & 0.5 & 0.5 & 0.5 & 0.5 \\
\hline $\begin{array}{l}\text { Turbidity } \\
\text { in Nephelometric Turbidity } \\
\text { Unit (NTU) }\end{array}$ & $0-50$ & 17 & 15 & 14 & 13 & 14 & 14 \\
\hline Hydrogen Potential $(\mathrm{pH})$ & $6-9$ & 7.21 & 7.22 & 7.37 & 7.28 & 7.16 & 7.19 \\
\hline $\begin{array}{l}\text { Biochemical oxygen demand } \\
\text { (BOD) } \mathrm{mg} \mathrm{l}^{-1}\end{array}$ & $0-100$ & 43 & 37 & 43 & 48 & 43 & 45 \\
\hline
\end{tabular}

Source: Own elaboration.

Table 3. Results of the Shapiro-Wilk test

\begin{tabular}{|l|l}
\hline Proof & P-value \\
\hline Shapiro-Wilk (Normal) & 0.11
\end{tabular}

Note. Data obtained by the $R$ Studio program. 
Source: Own elaboration.

Table 4. Result of the Shapiro-Wilk and Levene test

\begin{tabular}{|ll}
\hline Tests & EPOCH \\
\hline Shapiro-Wilk (Normal) & 0.95 \\
\hline Levene (Homogeneity) & 0.34 \\
\hline
\end{tabular}

Note. Data obtained by the R Studio program.

Source: Own elaboration.

Table 5. Comparison of the EPOCH Microplate Spectrophotometer method (biosensor) vs the UV-visible method (Colorimetry) to quantify $0.05 \mathrm{mg} \mathrm{r}^{-1}$ of chromium

\begin{tabular}{llll}
$\begin{array}{l}\text { Chromium concentration } \text { (mg l- }^{-} \\
\left.{ }^{1}\right)\end{array}$ & $\begin{array}{l}\text { EPOCH } \\
(\text { BIOSENSOR) } \\
\left(\mathrm{mg} \mathrm{l}^{-1}\right)\end{array}$ & $\begin{array}{l}\text { UV-visible } \\
\text { (Colorimeter) }\end{array}$ & $\begin{array}{l}\text { P-value } \\
\text { (calculated statistical } \\
\text { value) }\end{array}$ \\
\hline 0.05 & 0.05 & 0.03 & 0.02 \\
\hline
\end{tabular}

Note. Data obtained by the R Studio program.

Source: Own elaboration.

Table 6. Comparison of the EPOCH Microplate Spectrophotometer method (biosensor) vs the UV-visible method (Colorimetry) to quantify $0.1 \mathrm{mg} \mathrm{r}^{-1}$ of chromium

\begin{tabular}{|c|c|c|c|}
\hline $\begin{array}{l}\text { Chromium concentration (mgl' } \\
\text { 1) }\end{array}$ & $\begin{array}{l}\text { EPOCH } \\
\text { (BIOSENSOR) } \\
\left(\mathrm{mg} \mathrm{l}^{-1}\right)\end{array}$ & $\begin{array}{l}\text { UV-visible } \\
\text { (Colorimeter) } \\
\left(\mathrm{mg} \mathrm{l}^{-1}\right)\end{array}$ & $\begin{array}{l}\text { P-value } \\
\text { (calculated statistical } \\
\text { value) }\end{array}$ \\
\hline 0.1 & 0.09 & 0.05 & 0.00024 \\
\hline
\end{tabular}

Note. Data obtained by the R Studio program.

Source: Own elaboration.

Table 7. Comparison of the EPOCH Microplate Spectrophotometer method (biosensor) vs the UV-visible method (Colorimetry) to quantify $0.2 \mathrm{mg}^{-1}$ of chromium 
Chromium concentration (mg l1)
EPOCH

(BIOSENSOR)

( $\mathrm{mg} \mathrm{l}^{-1}$ )
UV-visible

(Colorimeter)

$\left(\mathrm{mg} \mathrm{l}^{-1}\right)$

\section{2}

0.2

0.09

0.07

Note. Data obtained by the R Studio program.

Source: Own elaboration.

Table 8. Comparison of the EPOCH Microplate Spectrophotometer method (biosensor) vs the UV-visible method (Colorimetry) to quantify $0.4 \mathrm{mg} \mathrm{r}^{-1}$ of chromium

\begin{tabular}{|c|c|c|c|}
\hline $\begin{array}{l}\text { Chromium concentration (mgl- } \\
\text { 1) }\end{array}$ & $\begin{array}{l}\text { EPOCH } \\
\text { (BIOSENSOR) } \\
\left(\mathrm{mg} \mathrm{l}^{-1}\right)\end{array}$ & $\begin{array}{l}\text { UV-visible } \\
\text { (Colorimeter) } \\
\left(\mathrm{mg} \mathrm{l}^{-1}\right)\end{array}$ & $\begin{array}{l}\text { P-value } \\
\text { (calculated statistical } \\
\text { value) }\end{array}$ \\
\hline 0.4 & 0.4 & 0.14 & 0.07 \\
\hline
\end{tabular}

Note. Data obtained by the $R$ Studio program.

Source: Own elaboration.

Table 9. Comparison of the EPOCH Microplate Spectrophotometer method (biosensor) vs the UV-visible method (Colorimetry) to quantify $0.8 \mathrm{mg} \mathrm{I}^{-1}$ of chromium

\begin{tabular}{llll}
$\begin{array}{l}\text { Chromium concentration } \text { (mg I- }^{-} \\
1)\end{array}$ & $\begin{array}{l}\text { EPOCH } \\
\text { (BIOSENSOR) } \\
\left(\mathrm{mg} \mathrm{l}^{-1}\right)\end{array}$ & $\begin{array}{l}\text { UV-visible } \\
\text { (Colorimeter) }\end{array}$ & $\begin{array}{l}\text { P-value } \\
\text { (calculated statistical } \\
\text { value) }\end{array}$ \\
\hline $\mathbf{~} \mathbf{( \mathrm { mg } \mathrm { l } ^ { - 1 } )}$ & 0.42 & 0.002 \\
\hline
\end{tabular}

Note. Data obtained by the $R$ Studio program.

Source: Own elaboration.

Table 10. Comparison of the EPOCH Microplate Spectrophotometer method (biosensor) vs the UV-visible method (Colorimetry) quantify $1.0 \mathrm{mg} \mathrm{r}^{-1}$ of chromium 


\begin{tabular}{llll}
$\begin{array}{l}\text { Chromium concentration } \text { (mg I- }^{-} \\
\mathbf{1}^{-}\end{array}$ & $\begin{array}{l}\text { EPOCH } \\
\text { (BIOSENSOR) } \\
\left(\mathrm{mg} \mathrm{l}^{-1}\right)\end{array}$ & $\begin{array}{l}\text { UV-visible } \\
\text { (Colorimeter) } \\
\left(\mathrm{mg} \mathrm{l}^{-1}\right)\end{array}$ & $\begin{array}{l}\text { P-value } \\
\text { (calculated statistical } \\
\text { value) }\end{array}$ \\
\hline 1.0 & 0.99 & 0.64 & 0.02
\end{tabular}

Note. Data obtained by the R Studio program.

Source: Own elaboration.

Table 11. Results of the analysis of river samples

\begin{tabular}{|c|c|c|c|}
\hline Samples & $\begin{array}{l}\text { Chromium concentration } \\
\text { (mg l-1) quantified by the } \\
\text { EPOCH (BIOSENSOR) }\end{array}$ & $\begin{array}{l}\text { Chromium concentration } \\
\text { (mg l-1) quantified by UV- } \\
\text { visible (Colorimeter) }\end{array}$ & $\begin{array}{l}\text { Chromium concentration } \\
\text { (mg l-1) quantified by } \\
\text { Atomic Absorption }\end{array}$ \\
\hline M1 & 0.21 & 0.10 & 0.20 \\
\hline M2 & 0.19 & 0.12 & 0.20 \\
\hline M3 & 0.15 & 0.09 & 0.15 \\
\hline M4 & 0.19 & 0.09 & 0.20 \\
\hline M5 & 0.20 & 0.07 & 0.20 \\
\hline M6 & 0.19 & 0.06 & 0.20 \\
\hline
\end{tabular}

Note. Data obtained by the R Studio program.

Source: Own elaboration.

\section{Figures}




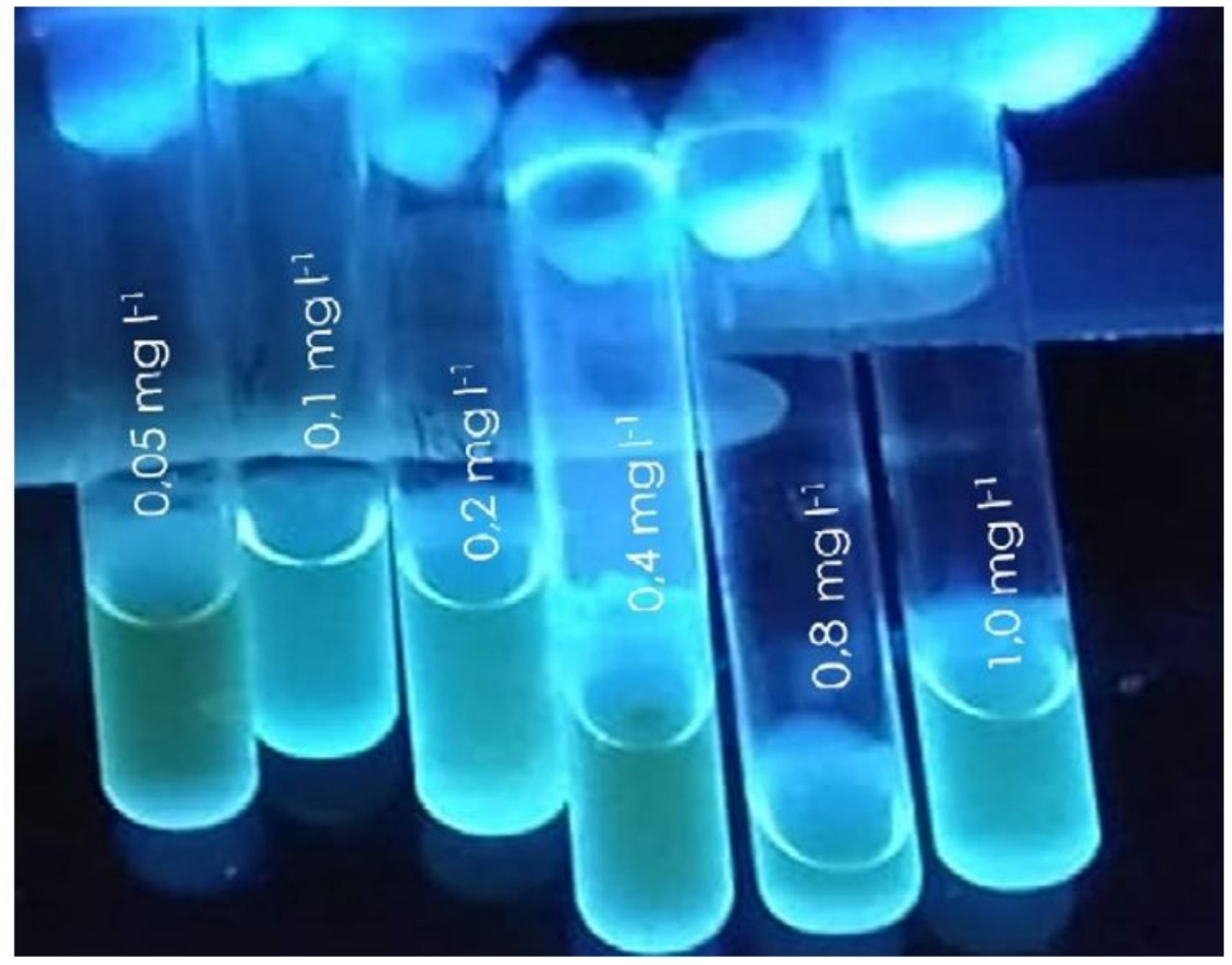

Figure 1

Qualification of the biosensor at different chromium concentrations Source: Own elaboration. 


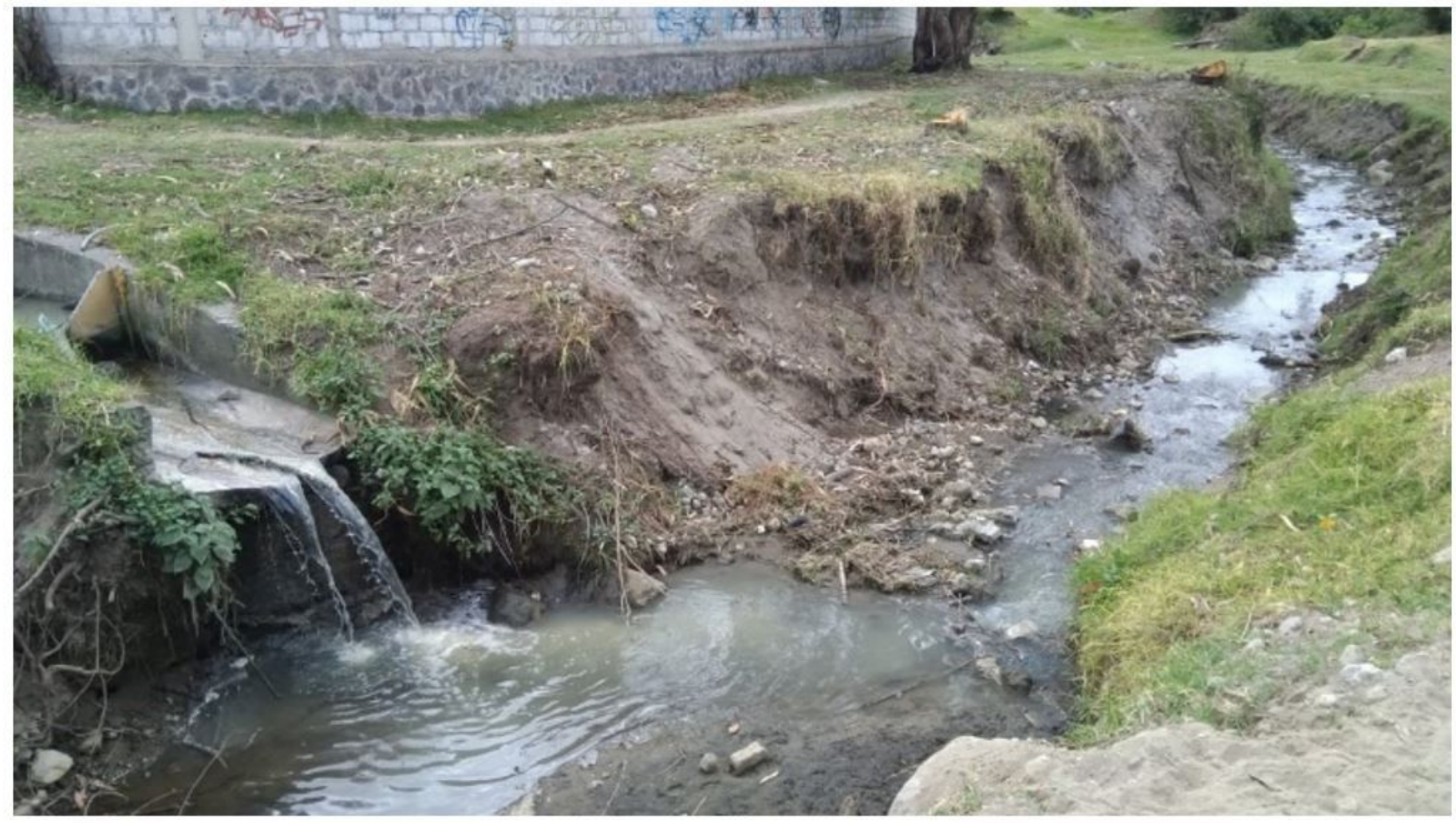

Figure 2

Urban wastewater discharge point to the Pichaví river Source: Own elaboration. 


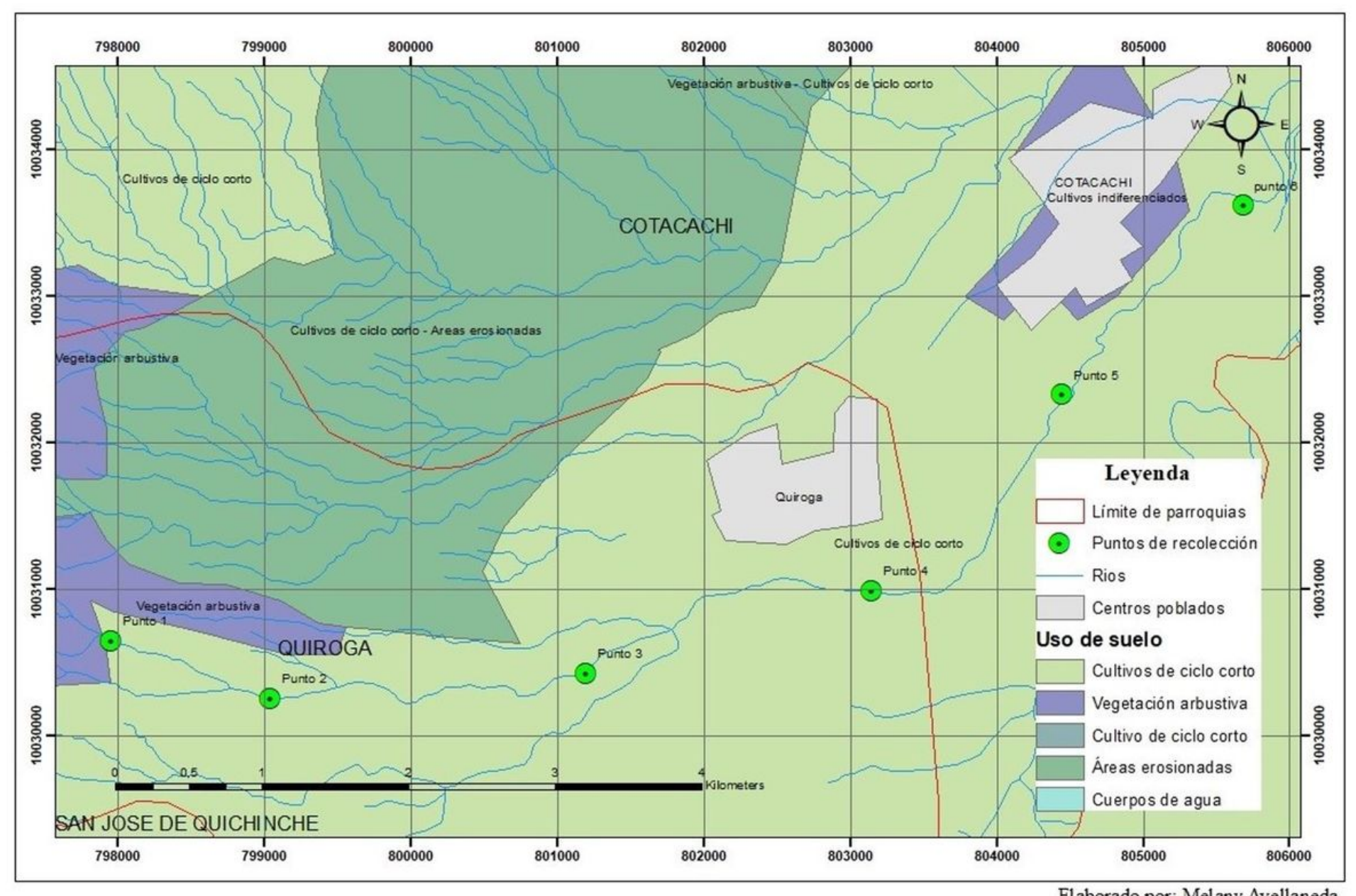

Elaborado por: Melany Avellaneda

\section{Figure 3}

Location of the water sampling of the Pichaví river Source: Own elaboration. 


\section{EPOCH}

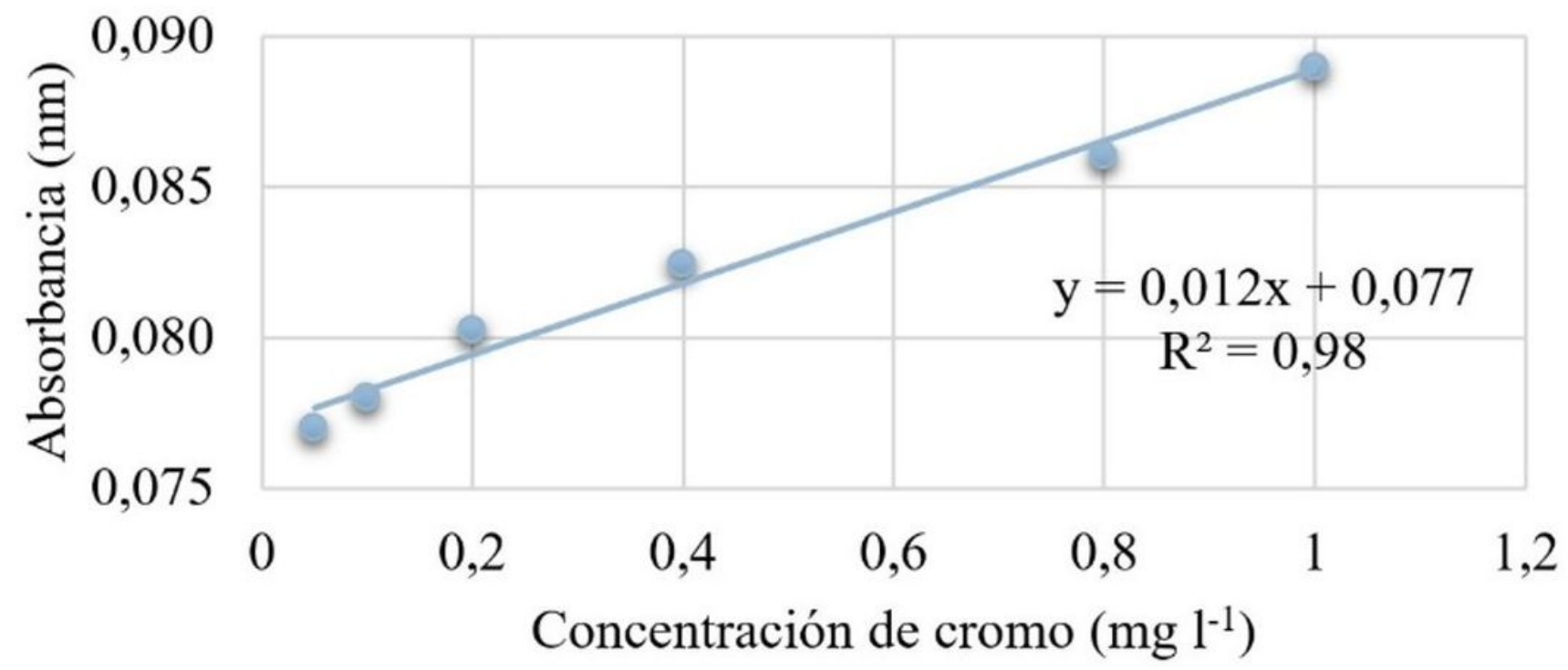

Figure 4

Absorbance of the EPOCH Microplate Spectrophotometer (BIOSENSOR) Source: Own elaboration.

\section{Supplementary Files}

This is a list of supplementary files associated with this preprint. Click to download.

- checklist.pdf 